\title{
The effect of $\mathrm{H}_{2} \mathrm{O}$ on formation mechanism of arsenic oxide during
}

\author{
arsenopyrite oxidation: Experimental and theoretical analysis
}

\author{
Chan Zou ${ }^{1}$, Chunbo Wang ${ }^{1 *}$, Liang Chen ${ }^{1}$, Yue Zhang ${ }^{1}$, Jiaying Xing ${ }^{1}$, Edward J. Anthony ${ }^{2}$ \\ ${ }^{1}$ Department of Energy, Power \& Mechanical Engineering, North China Electric Power \\ University, Baoding 071003, China \\ ${ }^{2}$ Cranfield University, Cranfield, Bedfordshire, MK43 0AL, UK
}

\begin{abstract}
The effect of $\mathrm{H}_{2} \mathrm{O}$ on arsenic release behavior was investigated via experiment and firstprinciples density functional theory (DFT). The experimental results show that sulfide-bound arsenic is the main form present in coal, and that $\mathrm{H}_{2} \mathrm{O}$ has a positive influence on the release of arsenic during coal combustion. Furthermore, DFT calculations were performed to investigate the mechanism for $\mathrm{H}_{2} \mathrm{O}$ influence on arsenic oxidation. Thermodynamic and kinetic analyses were also conducted to study the influence of temperature on the reaction process. From thermodynamic analysis, arsenic oxide formation on the $\mathrm{FeS}_{2}(100)$ surface with and without $\mathrm{H}_{2} \mathrm{O}$ weakens with increasing temperature. In addition, the equilibrium constant for the reaction with $\mathrm{H}_{2} \mathrm{O}$ addition is slightly higher than that for the reaction without $\mathrm{H}_{2} \mathrm{O}$, which suggests that the degree of the chemical reaction in the presence of $\mathrm{H}_{2} \mathrm{O}$ should increase. From kinetic analysis, the reaction rate constants increase with temperature, and the activation energy of the arsenic oxide formation reaction with and without $\mathrm{H}_{2} \mathrm{O}$ is $100.72 \mathrm{~kJ} / \mathrm{mol}$ and $124.08 \mathrm{~kJ} / \mathrm{mol}$, respectively. This indicates that $\mathrm{H}_{2} \mathrm{O}$ adsorption on the surface can decrease the energy barrier and accelerate the reaction forming arsenic oxide. Based on the thermodynamic and kinetic analyses, it can be concluded that temperature has an inhibitory influence on reaction equilibrium and positive influence on the reaction rate. The experiment and calculation results explain the influence of $\mathrm{H}_{2} \mathrm{O}$ on the formation mechanism of arsenic oxide and provide a theoretical foundation for the emission and control of arsenic.
\end{abstract}

Key words: $\mathrm{H}_{2} \mathrm{O}$; formation mechanism; arsenic oxide; arsenopyrite; density functional theory

\section{Highlights}

$\mathrm{H}_{2} \mathrm{O}$ effect on arsenic release was investigated by experiment and DFT calculation.

Sulfide-bound arsenic is the main arsenic form in coal.

Mechanism for $\mathrm{H}_{2} \mathrm{O}$ influence on arsenic oxidation from arsenopyrite were elucidated.

$\mathrm{H}_{2} \mathrm{O}$ reduces the energy barrier of arsenic oxide formation on the $\mathrm{FeS}_{2}(100)$ surface.

\section{Introduction}

Due to growing environmental awareness, more attention is being paid to the release of hazardous trace elements during coal combustion [1-3]. Arsenic released from coal-fired power plants is attracting increasing attention because of its teratogenicity, bioaccumulation and carcinogenicity [4-6]. In China, arsenic emission to the atmosphere was almost 213 tonnes from coal combustion in 2015 [7]. In the combustion of coal, arsenic is oxidized as arsenic oxides through a complex series of reactions. Thus, a clear understanding of the reaction processes can contribute an understanding of the formation and elimination of gaseous arsenic oxides emissions. 
The mode of occurrence and arsenic content vary from coal to coal, and there exist several dominant forms of arsenic in coal: organic, pyrite, and arsenate [8-10]. Previous researchers have come to the conclusion that arsenic occurs preferentially in pyrite and it can replace pyritic sulfur. Thus, Savage et al. [11] employed an electron probe micro-analyzer (EPMA) to explore arsenic speciation in pyrite, and found that arsenic exists in the form of a solid solution. In the research of Ruppert et al. [12], it was found that arsenic in coal is mainly correlated with pyrite. Pape et al. [13] performed experimental and theoretical research to explore the modes of arsenic incorporation into pyrite. From these studies, it can be concluded that pyrite in coal is enriched in arsenic, and it is of great importance to investigate the release mechanism of arsenic during arsenopyrite oxidation.

In recent years, several studies have focused on the release characteristics of arsenic [14-16]. In the research of Zou et al. [17], combustion experiments were conducted to investigate the volatilization of arsenic, and the results showed that arsenic release is mainly dependent on oxidative decomposition of sulfide-bound arsenic. Liu et al. [18] conducted combustion experiments to investigate the simultaneous release behavior of sulfur and arsenic in an isothermal thermogravimetric reactor, and found that the content of sulfide-bound arsenic in coal has a positive influence on the arsenic release. Those conclusions indicate that arsenic release during coal combustion is associated with sulfide-bound arsenic. However, the oxidation mechanism of arsenic is still unclear.

In flue gas, oxide compounds are the dominant arsenic species. In the research of Contreras et al. [19], thermodynamic equilibrium calculations were conducted to study the release and migration characteristics of arsenic, and calculation results showed that $\mathrm{AsO}_{2}(\mathrm{~g})$ and $\mathrm{AsO}(\mathrm{g})$ are the most common species when the temperature is above $800^{\circ} \mathrm{C}$. Liu et al. [20] explored the transformation of arsenates in an oxidizing atmosphere or a reducing atmosphere by thermodynamic equilibrium calculations. It was found that $\mathrm{AsO}(\mathrm{g})$ is the main product with increasing temperature. It can be noted that the abovementioned works focused mainly on the transformation of arsenic species via thermodynamic equilibrium calculations, while the kinetics of these transformations were neglected.

To date, only a few works have explored the reactions between arsenic and other gas compounds. Zou et al. [21] studied the reaction mechanisms between nitrogen oxides and arsenic using Gaussian software, and found that the arsenic atoms could be oxidized to $\mathrm{AsO}(\mathrm{g})$. In the research of Monahan-Pendergas et al. [22], the reaction mechanisms between arsenic atoms and radicals $\left(\mathrm{OH}, \mathrm{HO}_{2}\right)$ were investigated. However, most studies look at the homogeneous reactions of arsenic, and no study has as yet explored the release process of arsenic from arsenopyrite during coal combustion. Unfortunately, all such studies are limited by the detection method and technical problems of measuring arsenic concentrations during combustion. In addition, it is difficult to clarify the reaction process accurately via experiments due to the inherently fast chemical reactions. Quantum chemistry calculations are, therefore, a useful way to study the reaction process, which can provide a molecular-level understanding of arsenic oxide formation during coal combustion [23-25].

In this work, combustion experiments were conducted to investigate the influence of $\mathrm{H}_{2} \mathrm{O}$ on the arsenic release behavior in a customized isothermal thermogravimetric reactor. Furthermore, the mechanism by which $\mathrm{H}_{2} \mathrm{O}$ influences the oxidation mechanism of arsenic was also studied via density functional theory (DFT) calculations. To achieve this, first, the adsorption characteristics of $\mathrm{O}_{2}$ and $\mathrm{H}_{2} \mathrm{O}$ on the $\mathrm{FeS}_{2}$ (100) surface were investigated to determine the most stable adsorption structure. Then, the detailed reaction pathways of arsenic oxide formation on the $\mathrm{FeS}_{2}(100)$ surface 
with or without $\mathrm{H}_{2} \mathrm{O}$ were explored. Finally, based on the analysis of reaction pathways, thermodynamic and kinetic analyses were conducted to study the influence of temperature on equilibrium constant and reaction rate constant.

\section{Materials and methods}

\subsection{Coal sample}

A bituminous coal (ST coal) was chosen for combustion experiments. The coal sample was airdried, crushed and sieved to a particle size of $0.10-0.15 \mathrm{~mm}$. The properties of ST coal are given in Table 1.

Table 1. Properties of ST coal sample.

\begin{tabular}{|c|c|c|c|c|c|c|c|c|c|}
\hline \multicolumn{5}{|c|}{ Ultimate analysis $w_{\text {ad }}, \%$} & \multicolumn{4}{|c|}{ Proximate analysis $w_{\text {ad, }} \%$} & \multirow{2}{*}{ arsenic, $\mu \mathrm{g} \cdot \mathrm{g}^{-1}$} \\
\hline $\mathrm{C}$ & $\mathrm{H}$ & $\mathrm{O}$ & $\mathrm{N}$ & $\mathrm{S}$ & M & A & V & $\mathrm{FC}$ & \\
\hline 51.02 & 2.70 & 5.81 & 0.83 & 0.38 & 0.55 & 38.71 & 11.39 & 49.35 & 4.99 \\
\hline \multicolumn{10}{|c|}{ Ash composition, $\%$} \\
\hline $\mathrm{Al}_{2} \mathrm{O}_{3}$ & $\mathrm{SiO}_{2}$ & & $\mathrm{CaO}$ & $\mathrm{Fe}_{2} \mathrm{O}_{3}$ & & & $\mathrm{TiO}_{2}$ & $\mathrm{SO}_{3}$ & $\mathrm{~K}_{2} \mathrm{O}$ \\
\hline 42.70 & 50.93 & & 1.70 & 1.99 & & & 1.47 & 0.60 & 0.55 \\
\hline
\end{tabular}

\subsection{Combustion system}

The isothermal thermogravimetric reactor was employed to conduct combustion experiments, and a schematic of the combustion system is shown in Fig. S1 in Supporting Information. The description of the combustion system and experimental procedure are described in our previous work [17].

\subsection{Sample analysis method}

In general, sequential chemical extraction is an effective method to determine arsenic speciation in coal or ash. The arsenic in a solid sample can be divided into four forms, namely exchangeable forms, organic forms, sulfide forms, and residual forms. The method is explained elsewhere [26], and the extraction process is shown schematically in Fig. 1. 


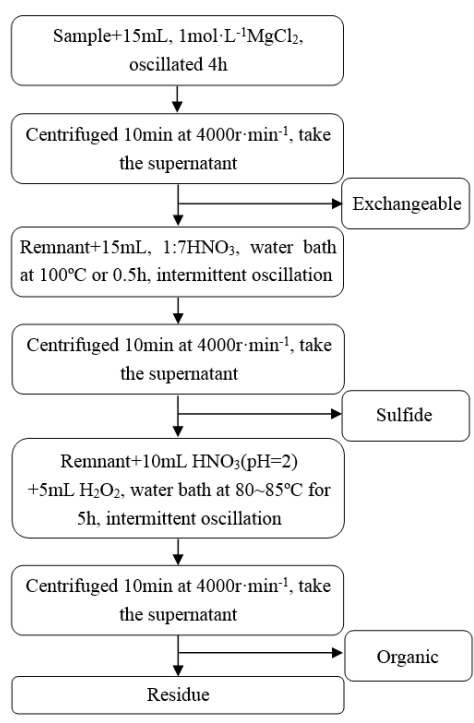

Fig. 1. Schematic of a sequential chemical extraction analysis.

The concentrations of arsenic in different supernatant fractions were tested with an atomic fluorescence spectrometer (made by the Jitian Company, China). The solid samples (raw coal and residue after sequential chemical extraction) must be digested before measurement to obtain the concentration of arsenic. More details on the digestion procedures can be found elsewhere $[17,26]$.

\subsection{Density functional theory (DFT) calculations}

\subsubsection{Calculation method}

Density functional theory and the Perdew-Burke-Ernzerhof (PBE) of generalized gradient approximation (GGA) method were applied to all calculations using the Vienna ab initio simulation package (VASP) [27]. In addition, the projector-augmented wave (PAW) basis set was employed to calculate the core-valence interaction $[28,29]$. Spin polarization was considered to obtain the accurate system energy. The energy cutoff and k-point grid were tested until the energy change was less than $10 \mathrm{meV} / \mathrm{atom}$. During the calculation process, the plane wave basis set was expanded to a $400 \mathrm{eV}$ energy cutoff to ensure convergence. The first Brillouin zone of $(1 \times 1) \mathrm{FeS}_{2}$ unit cell was sampled by the Monkhorst-Pack k-points with $4 \times 4 \times 4$ grid mesh. In addition, a $2 \times 2 \times 1$ grid mesh was adopted to sample the first Brillouin zone for $(2 \times 2)$ slab model, and a denser $4 \times 4 \times 1$ grid mesh was adopted to more accurately calculate energy. The climbing-image nudged-elastic-band (CINEB) method [30] was used to determine the transition states, which were confirmed by checking imaginary frequency. For all of the calculations, the bottom six layers were fixed and the top layers were free to relax with energy change tolerance of $10^{-5} \mathrm{eV}$ for reactant or product optimization and $10^{-7} \mathrm{eV}$ for transition states' optimization, and force convergence standard of $0.05 \mathrm{eV} / \AA$. The unit cell of $\mathrm{FeS}_{2}$ is a NaCl-like structure (Pa3 space group) with the face-centered cubic crystal structure. The $\mathrm{FeS}_{2}$ bulk can be characterized by two structural parameters, a (the lattice constant), and $\mathrm{u}$ (the internal coordinate of $\mathrm{S}$ from the face of the unit cell). The calculated lattice parameters $(\mathrm{a}=5.405$ $\AA, \mathrm{u}=0.383)$, are very close to the experimental data $(\mathrm{a}=5.418 \AA, \mathrm{u}=0.385)[31,32]$. Therefore, the abovementioned theoretical methods are reliable.

The formation energy $(\Delta E)$ means the decrease in energy when an arsenic atom is incorporated into the pyrite. $\Delta E$ is calculated from the following formula:

$\Delta E=E_{\mathrm{P}}-E_{\mathrm{R}}-E_{\mathrm{A}}$ 
where $E_{\mathrm{P}}$ is the total energy of the pyrite with arsenic, and $E_{\mathrm{R}}$ and $E_{\mathrm{A}}$ correspond to the energy of pyrite and arsenic, respectively. Basically, a lower value of $\Delta E$ implies that the arsenic species is more stable. To describe the adsorption strength of gases $\left(\mathrm{H}_{2} \mathrm{O}\right.$ and $\left.\mathrm{O}_{2}\right)$ on the $\mathrm{FeS}_{2}(100)$ surface, the adsorption energy $\left(E_{\mathrm{ads}}\right)$ was obtained by calculating the formula:

$E_{\mathrm{ads}}=E_{(\mathrm{AB})}-\left(E_{(\mathrm{A})}+E_{(\mathrm{B})}\right)$

Here, $E_{(\mathrm{AB})}, E_{(\mathrm{A})}$, and $E_{(\mathrm{B})}$ are the energy of the system after adsorption, gas molecules $\left(\mathrm{H}_{2} \mathrm{O}\right.$ and $\left.\mathrm{O}_{2}\right)$ and the $\mathrm{FeS}_{2}$, respectively.

The energy barrier $\left(E_{\mathrm{b}}\right)$ and reaction heat $\left(E_{\mathrm{h}}\right)$ were used to describe the reaction process, and those parameters can be calculated by the following formulas:

$E_{\mathrm{b}}=E_{\mathrm{TS}}-E_{\mathrm{IS}}$

$E_{\mathrm{h}}=E_{\mathrm{IM}}-E_{\mathrm{IS}}$

where $E_{\mathrm{IS}}, E_{\mathrm{IM}}$ and $E_{\mathrm{TS}}$ are the energy of the initial, intermediate and transition states, respectively. Thermodynamic parameters were calculated to analyze the reaction process, and the equilibrium constant is calculated by the following formula [33]:

$\Delta G=G_{\mathrm{P}}-G_{\mathrm{R}}=-R T \ln K$

where $G_{\mathrm{R}}$ and $G_{\mathrm{P}}$ are the Gibbs free energy of reactants and products, respectively, $\mathrm{K}$ is the equilibrium constant, $R$ is the gas constant and $T$ is the reaction temperature. In addition, the Gibbs free energy of each system is calculated by the following formulas [4, 34-36]:

$G_{\text {Solid }}=E_{\text {ele }}+Z P E-T * S$

$G_{\text {Gas }}=E_{\text {ele }}+Z P E+R * T-T * S$

where $E_{\text {ele }}$ is the single point energy, and $Z P E$ and $S$ are the zero-point energy correction and the entropy.

According to the conventional transition state theory, kinetic parameters were calculated at $298.15-1500 \mathrm{~K}$, and the formula used is as follows [37, 38]:

$k=\frac{k_{\mathrm{B}} T}{h} \times \exp \left(\frac{-\Delta G_{\mathrm{b}}}{R T}\right)$

where $h$ is the Planck constant; $\Delta G_{\mathrm{b}}$ is the energy barrier in Gibbs energy; $k_{\mathrm{B}}$ is the Boltzmann constant; and $T$ is the reaction temperature.

\subsubsection{Calculation model}

According to previous studies [12,39], arsenic in $\mathrm{FeS}_{2}$ occurs in two dominant forms: that are enclosed in the microstructure; and which act as a substitute for sulfur. In addition, many studies have pointed out that the (100) plane of $\mathrm{FeS}_{2}$ is the most stable [40-43]. Thus, the $\mathrm{FeS}_{2}$ (100) was employed to explore the volatilization mechanism of arsenic. An arsenic structure was constructed to systematically investigate the volatilization mechanism of arsenic during arsenopyrite oxidation. To prevent spurious image interactions, a $2 \times 2$ supercell $\mathrm{FeS}_{2}$ with a $20 \AA$ vacuum layer was established. The optimized geometric structures are shown in Fig. S2, and Table S1 lists some important parameters (formation energy, electron transfer, and bond length) in Supporting Information.

\section{Results and discussion}

\subsection{Effect of $\mathrm{H}_{2} \mathrm{O}$ on the volatilization percentage of arsenic}


Normally, $\mathrm{H}_{2} \mathrm{O}$ is a major component during coal combustion, and its concentration may be up to $15 \%-35 \%$ due to flue gas recycle for oxy-fired systems, for example [44-46]. To investigate the role of $\mathrm{H}_{2} \mathrm{O}$, arsenic volatilization percentage with different $\mathrm{H}_{2} \mathrm{O}$ concentrations $(0,10 \%, 20 \%$, and $30 \%$ ) was studied in the range of $800-1300^{\circ} \mathrm{C}$. The experimental result are presented in Fig. 2.

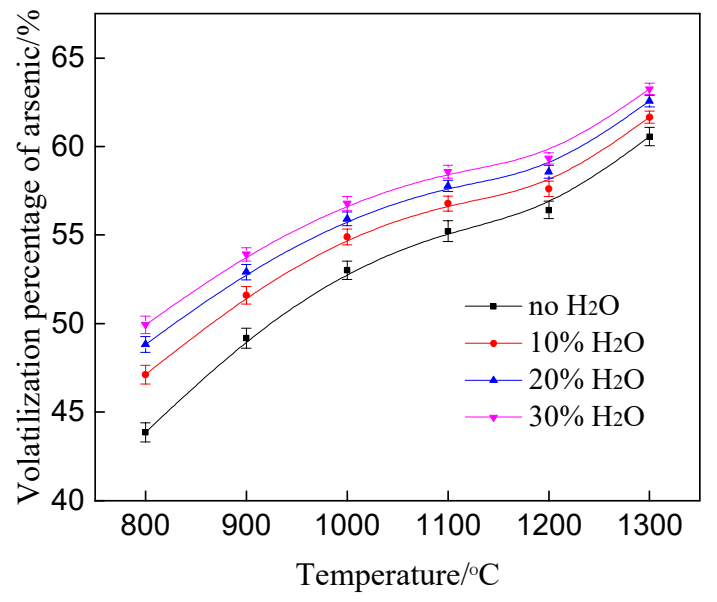

Fig. 2. The volatilization percentage of arsenic at different temperatures for ST coal.

In Fig. 2, the release ratios of arsenic gradually became higher with increasing combustion temperature. The arises because a higher temperature accelerates coal combustion, and increases the volatilization percentage of arsenic. In addition, the promotional effect of $\mathrm{H}_{2} \mathrm{O}$ on the volatilization of arsenic decreases as the percent $\mathrm{H}_{2} \mathrm{O}$ increases. To explain the effect of $\mathrm{H}_{2} \mathrm{O}$ on arsenic release, the mode of occurrence of arsenic in coal and its ash were measured, and the results are presented in Fig. 3.

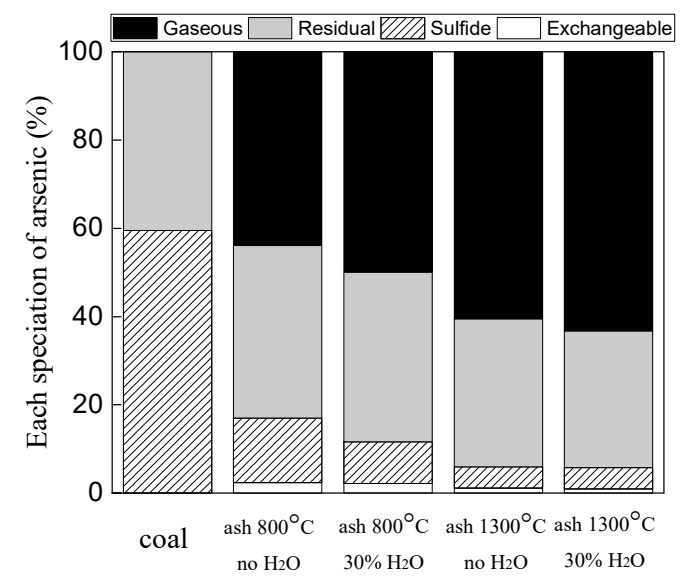

Fig. 3. Mode of occurrence of arsenic in ST coal and its ash.

In Fig. 3, it can been seen that about $60 \%$ of the arsenic in raw coal is sulfide-bound, which confirms previous experiment results $[11,12]$. Compared to the raw coal, there is a large decrease in the percentage of sulfide-bound arsenic in ash after coal combustion. In addition, at $800{ }^{\circ} \mathrm{C}$, the release ratio of arsenic with $30 \% \mathrm{H}_{2} \mathrm{O}$ is larger than that without $\mathrm{H}_{2} \mathrm{O}$. From Fig. 3, the increase of arsenic volatilization percentage with $30 \% \mathrm{H}_{2} \mathrm{O}$ is due to $\mathrm{H}_{2} \mathrm{O}$ promoting the oxidation of sulfidebound arsenic at $800{ }^{\circ} \mathrm{C}$, while there is only a small difference in arsenic volatilization percentage with either no $\mathrm{H}_{2} \mathrm{O}$ or with $30 \% \mathrm{H}_{2} \mathrm{O}$ at $1300{ }^{\circ} \mathrm{C}$. The reason is that sulfide-bound arsenic is almost totally decomposed, and the increase of the arsenic volatilization percentage with $30 \% \mathrm{H}_{2} \mathrm{O}$ is due 
to the decomposition of arsenic minerals. Arsenic in minerals with high thermostability are difficult to decompose [47], resulting in a small increase of the release ratio of arsenic with $\mathrm{H}_{2} \mathrm{O}$ at $1300{ }^{\circ} \mathrm{C}$. The results show that the main arsenic form in coal is sulfide-bound, and $\mathrm{H}_{2} \mathrm{O}$ has a positive effect on the arsenic release during coal combustion.

\subsection{Formation mechanism of arsenic oxide}

\subsubsection{Adsorption of $\mathrm{O}_{2}$ on $\mathrm{FeS}_{2}$ (100) surface}

$\mathrm{O}_{2}$ adsorption on the $\mathrm{FeS}_{2}(100)$ surface is the foundation of arsenic oxide formation. There exist different active adsorption sites on the $\mathrm{FeS}_{2}(100)$ surface. In addition, $\mathrm{O}_{2}$ adsorption can occur vertically as well as horizontally. During the calculation process, all possible configurations of $\mathrm{O}_{2}$ adsorption on the $\mathrm{FeS}_{2}$ (100) surface were taken into account, and some reasonable structures after calculation are presented in Fig. 4. Some important parameters (adsorption energy and bond length) are given in Table 2 .

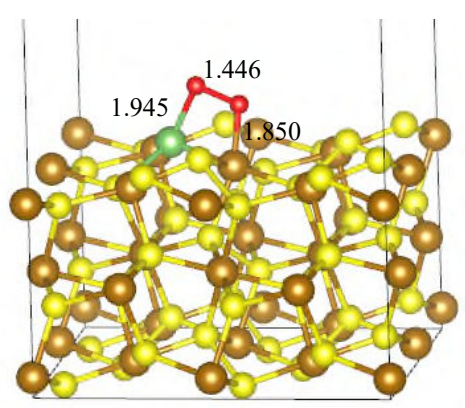

$4 \mathrm{~A}$

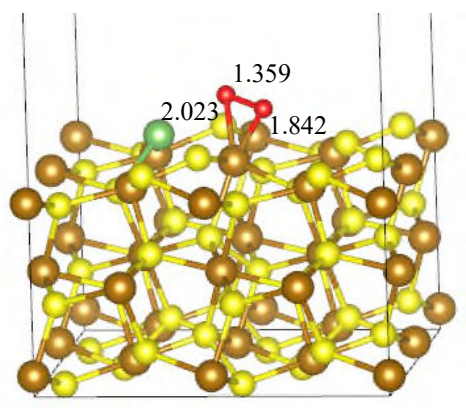

4B

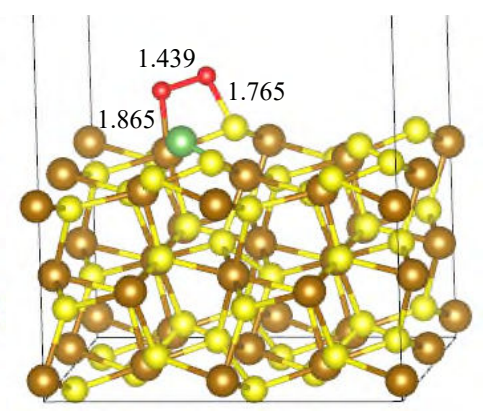

$4 \mathrm{C}$

Fig. 4. Optimized structures of $\mathrm{O}_{2}$ adsorption on $\mathrm{FeS}_{2}(100)$ surface. The $\mathrm{O}$ atom is red.

Table 2. Adsorption energy $\left(E_{\text {ads }}\right)$ and bond length for $\mathrm{O}_{2}$ adsorption on $\mathrm{FeS}_{2}(100)$.

\begin{tabular}{cccc}
\hline Structure & $E_{\text {ads }}(\mathrm{kJ} / \mathrm{mol})$ & $\mathrm{RX}_{\mathrm{X}-\mathrm{O}}(\AA)$ & $\mathrm{R}_{\text {O-O }}(\AA)$ \\
\hline $4 \mathrm{~A}$ & -107.86 & $1.945 / 1.850$ & 1.446 \\
$4 \mathrm{~B}$ & -46.95 & $2.023 / 1.842$ & 1.359 \\
$4 \mathrm{C}$ & -26.54 & $1.865 / 1.765$ & 1.439 \\
\hline
\end{tabular}

$\mathrm{X}$ denotes the atom on surface

In structure $4 \mathrm{~A}$, the $\mathrm{O}_{2}$ molecule interacts with $\mathrm{Fe}$ and $\mathrm{As}$ atoms on the surface to form $\mathrm{Fe}-\mathrm{O}$ bond $(1.850 \AA)$ and $\mathrm{As}-\mathrm{O}$ bond $(1.945 \AA)$. The adsorption process is exothermic with an energy of $-107.86 \mathrm{~kJ} / \mathrm{mol}$. For structure $4 \mathrm{~B}, \mathrm{O}_{2}$ is horizontally adsorbed on the top of the Fe site with an adsorption energy of $-46.95 \mathrm{~kJ} / \mathrm{mol}$. The distances of two $\mathrm{Fe}-\mathrm{O}$ bonds are $2.023 \AA$ and $1.842 \AA$, respectively. Compared with structures $4 \mathrm{~A}$ and $4 \mathrm{~B}$, structure $4 \mathrm{C}$ is the most unstable with an adsorption energy of $-26.54 \mathrm{~kJ} / \mathrm{mol}$. The distances of $\mathrm{Fe}-\mathrm{O}$ and $\mathrm{S}-\mathrm{O}$ bond are $1.865 \AA$ and 1.765 $\AA$, respectively, during the $\mathrm{O}_{2}$ molecule adsorption process. From the analysis above, the $\mathrm{O}_{2}$ adsorption process is identified as chemical adsorption or physical absorption depending on the adsorption energy. It can be demonstrated that the structure of the $\mathrm{O}_{2}$ adsorption on a bridge site between $\mathrm{As}$ and $\mathrm{Fe}$ atoms (structure 4A) is more stable than that of the $\mathrm{O}_{2}$ adsorption on a Fe site (structure 4B) or bridge site between $\mathrm{S}$ and $\mathrm{Fe}$ atom (structure 4C). Therefore, the $\mathrm{O}_{2}$ molecule is likely to adsorb on a bridge site between $\mathrm{As}$ and $\mathrm{Fe}$ atoms in the process of arsenic oxide formation on the $\mathrm{FeS}_{2}(100)$ surface.

\subsection{2 $\mathrm{H}_{2} \mathrm{O}$ adsorption on $\mathrm{FeS}_{2}$ (100) surface}

To investigate the influence of $\mathrm{H}_{2} \mathrm{O}$ on the release mechanism of arsenic during arsenopyrite 
oxidation, it is necessary to first analyze $\mathrm{H}_{2} \mathrm{O}$ adsorption on the $\mathrm{FeS}_{2}$ (100) surface. In this work, different orientations of $\mathrm{H}_{2} \mathrm{O}$ adsorption on the active sites of the $\mathrm{FeS}_{2}(100)$ surface were considered. Fig. 5 shows six configurations of $\mathrm{H}_{2} \mathrm{O}$ adsorption on the surface, and some important parameters (adsorption energy and bond length) are given in Table 3.

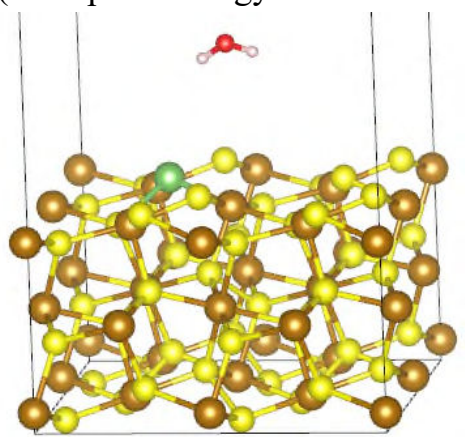

$5 \mathrm{~A}$

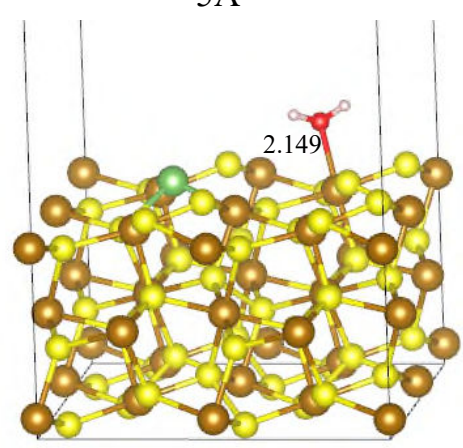

$5 \mathrm{D}$

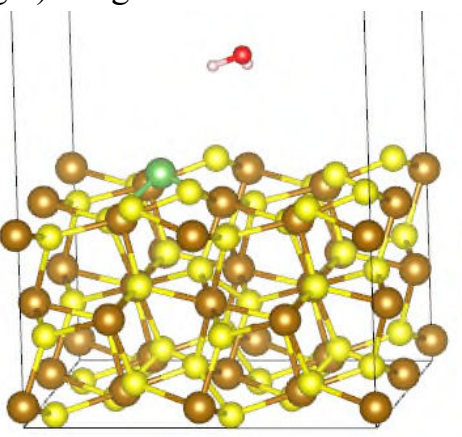

$5 \mathrm{~B}$

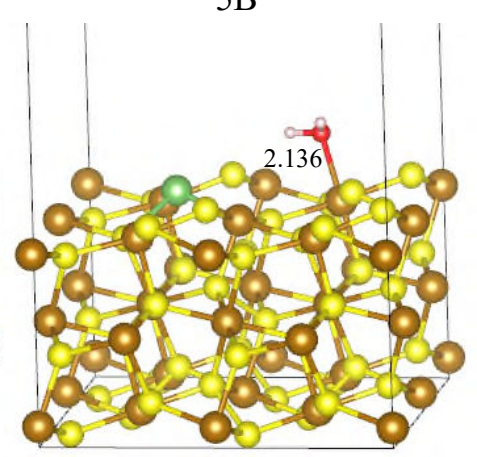

$5 \mathrm{E}$

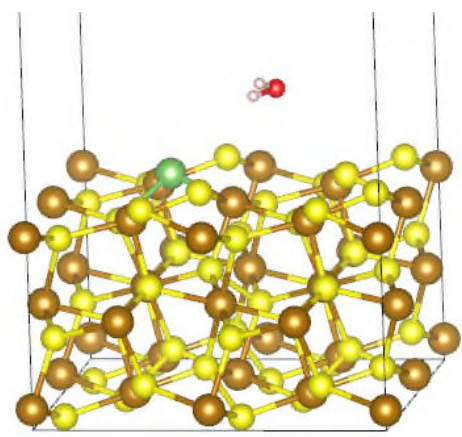

$5 \mathrm{C}$

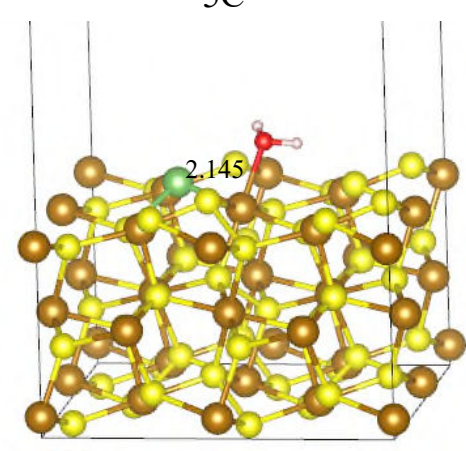

$5 \mathrm{~F}$

Fig. 5. Optimized structures of $\mathrm{H}_{2} \mathrm{O}$ adsorption on $\mathrm{FeS}_{2}$ (100) surface. The hydrogen atom is white.

Table 3. Adsorption energy $\left(E_{\text {ads }}\right)$ and bond length for $\mathrm{H}_{2} \mathrm{O}$ adsorption on $\mathrm{FeS}_{2}(100)$.

\begin{tabular}{ccc}
\hline Structure & $E_{\text {ads }}(\mathrm{kJ} / \mathrm{mol})$ & $\mathrm{RX}_{\text {X-O }}(\AA)$ \\
\hline $5 \mathrm{~A}$ & -2.24 & $\infty$ \\
$5 \mathrm{~B}$ & -3.01 & $\infty$ \\
$5 \mathrm{C}$ & -10.94 & $\infty$ \\
$5 \mathrm{D}$ & -51.00 & 2.149 \\
$5 \mathrm{E}$ & -61.00 & 2.136 \\
$5 \mathrm{~F}$ & -56.87 & 2.145 \\
\hline
\end{tabular}

$\mathrm{X}$ denotes the atom on surface. $\infty$ means that the distance exceeds the bonding range.

As can be seen in Table 3, adsorption energies of structures 5A, 5B, and 5C are $-2.24 \mathrm{~kJ} / \mathrm{mol}$, $-3.01 \mathrm{~kJ} / \mathrm{mol}$, and $-10.94 \mathrm{~kJ} / \mathrm{mol}$, respectively. This shows there is physical absorption between $\mathrm{H}_{2} \mathrm{O}$ and the $\mathrm{FeS}_{2}$ (100) surface. The main reason is that the distance is too long, resulting in weak interaction between $\mathrm{H}_{2} \mathrm{O}$ and the $\mathrm{FeS}_{2}(100)$ surface. For structures $5 \mathrm{D}, 5 \mathrm{E}$, and $5 \mathrm{~F}$, there seems to be a weak chemical reaction between $\mathrm{H}_{2} \mathrm{O}$ and the $\mathrm{FeS}_{2}$ (100) surface, with the adsorption energy ranging from $-61.00 \mathrm{~kJ} / \mathrm{mol}$ to $-51.00 \mathrm{~kJ} / \mathrm{mol}$, which is relatively close to the result $(-41.8 \mathrm{~kJ} / \mathrm{mol}$ and $-63.00 \mathrm{~kJ} / \mathrm{mol}$ ) of Guevremont et al. [48, 49]. Structure $5 \mathrm{E}$ is the most stable with an adsorption energy of $-61.00 \mathrm{~kJ} / \mathrm{mol}$. The length of the $\mathrm{Fe}-\mathrm{O}$ bond is $2.136 \AA$ as $\mathrm{H}_{2} \mathrm{O}$ was adsorbed on the top of a surface $\mathrm{Fe}$ atom. Similar to structure $5 \mathrm{E}, \mathrm{H}_{2} \mathrm{O}$ was adsorbed on the same $\mathrm{Fe}$ atom in a different direction for structure $5 \mathrm{D}$. The adsorption energy is $-51.00 \mathrm{~kJ} / \mathrm{mol}$ for structure $5 \mathrm{D}$, which is a little larger than that for structure $5 \mathrm{E}$. The equilibrium distance of the $\mathrm{Fe}-\mathrm{O}$ bond is $2.149 \AA$. In structure $5 \mathrm{~F}$, the $\mathrm{O}$ atom of the $\mathrm{H}_{2} \mathrm{O}$ molecule is adsorbed on a $\mathrm{Fe}$ atom next to the As atom, and the distance 
of the $\mathrm{Fe}-\mathrm{O}$ bond is $2.145 \AA$. From the analysis above, it can be seen that the structures of the $\mathrm{H}_{2} \mathrm{O}$ adsorption on a surface $\mathrm{Fe}$ atom (structures $5 \mathrm{D}, 5 \mathrm{E}$, and $5 \mathrm{~F}$ ) are more stable than on other sites (structures 5A, 5B, and 5C) on the $\mathrm{FeS}_{2}(100)$ surface. Thus, it can be concluded that the $\mathrm{H}_{2} \mathrm{O}$ molecule is likely to adsorb on a surface Fe site [50].

\subsubsection{Arsenic oxide formation on $\mathrm{FeS}_{2}$ (100) surface}

From the calculation results in sections 3.2.1 and 3.2.2, the most stable structures for $\mathrm{O}_{2}$ and $\mathrm{H}_{2} \mathrm{O}$ molecule adsorption on the $\mathrm{FeS}_{2}(100)$ surface were selected to investigate the effect of $\mathrm{H}_{2} \mathrm{O}$ on the arsenic oxide formation reaction. The energies relative to the reactants and optimized structures of each stationary point for arsenic oxide formation are presented in Fig. 6. The major bond lengths of reactants, intermediates, transition states and products are also provided.

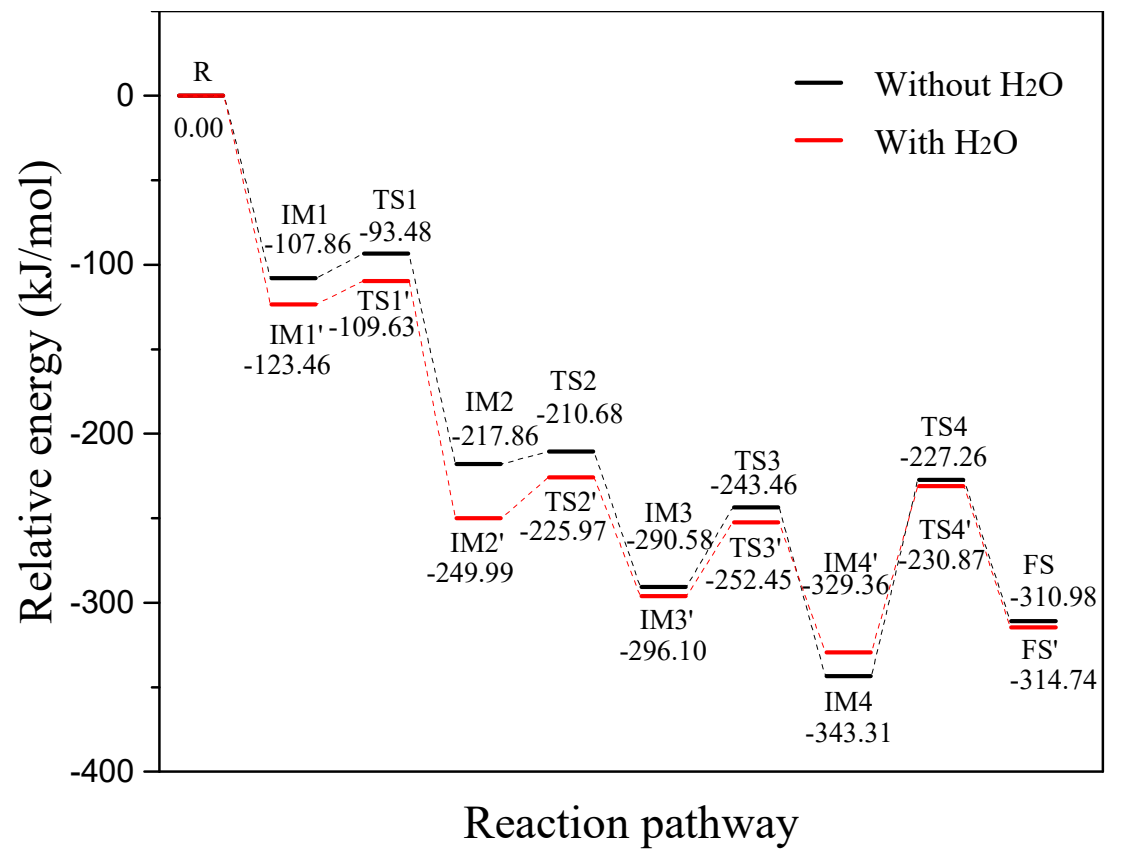

(a)

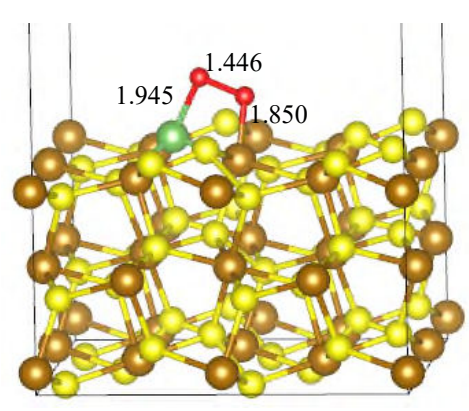

IM1

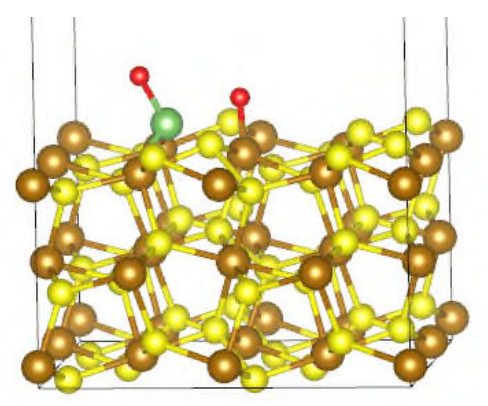

TS1

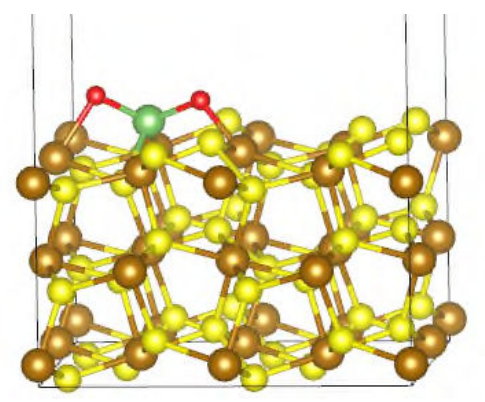

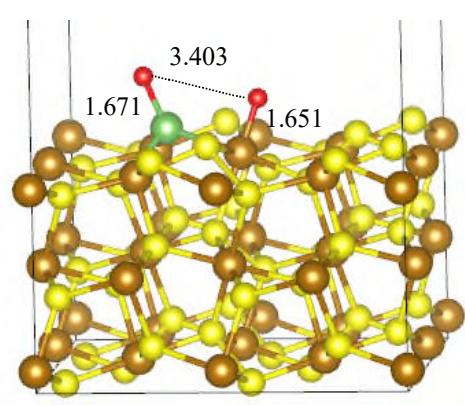

IM2

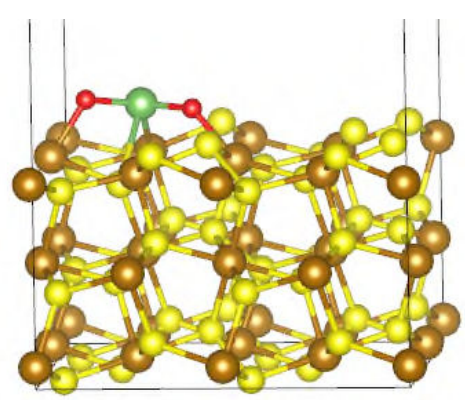




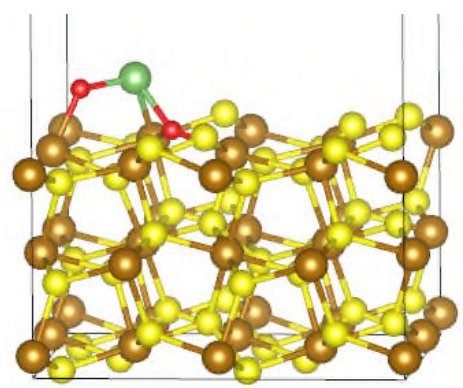

IM4

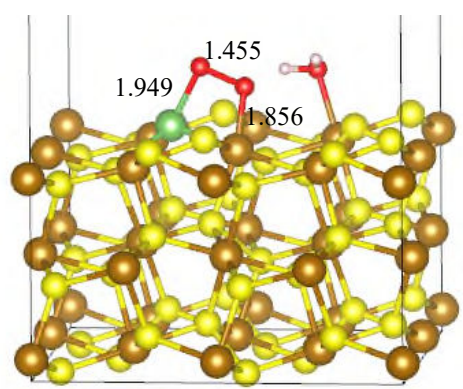

IM1'

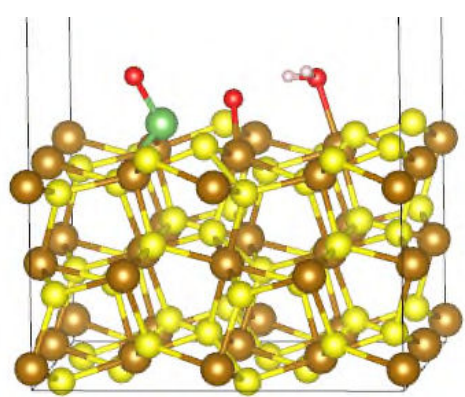

TS2'

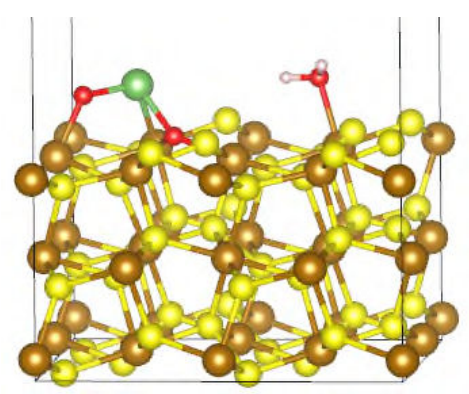

IM4'

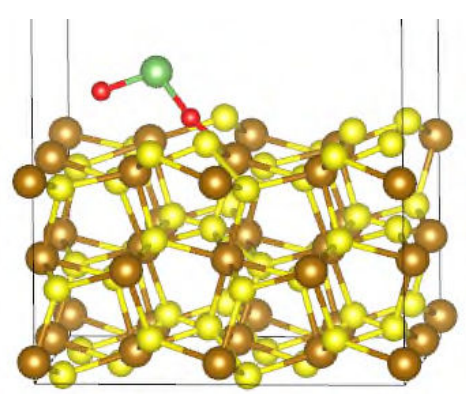

TS4

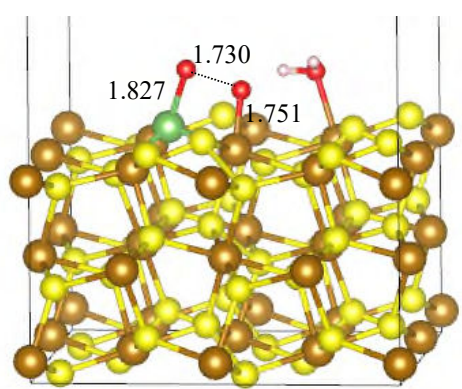

TS1'

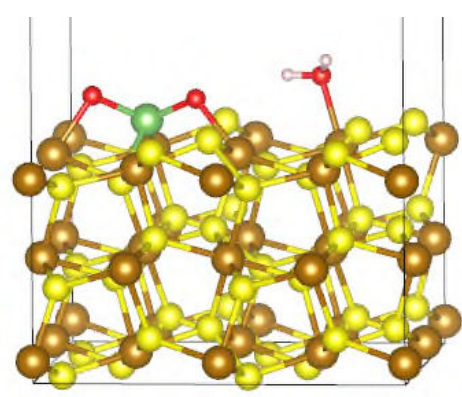

IM3'

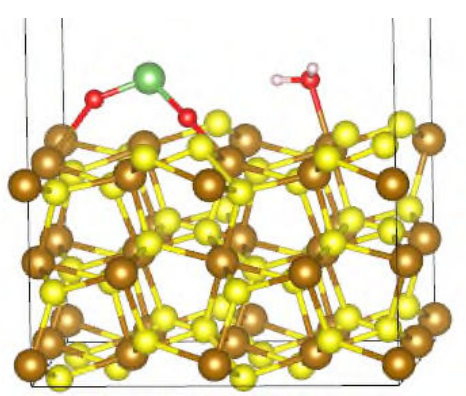

TS4'

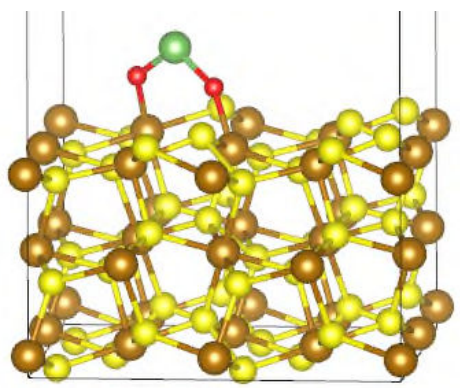

FS

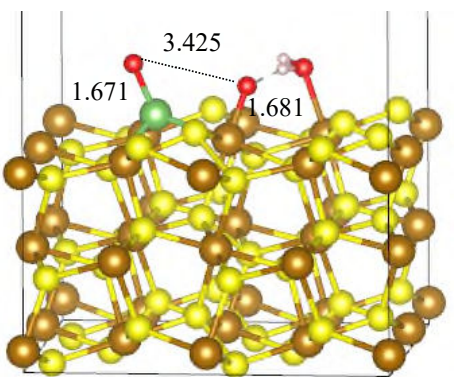

IM2'

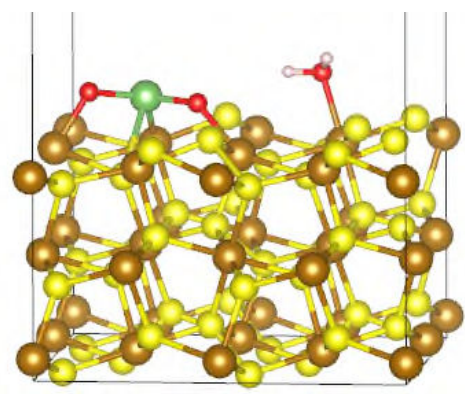

TS3'

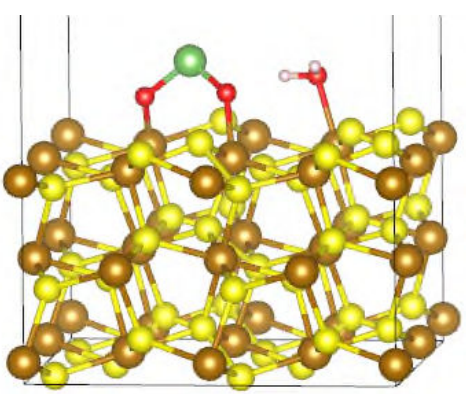

FS'

(b)

Fig. 6. Reaction potential energy profiles (a) and optimized structures (b) of arsenic oxide formation on $\mathrm{FeS}_{2}(100)$ surface.

As shown in Fig. 6(a), there are four transition states and four intermediates in the process of arsenic oxide formation on the $\mathrm{FeS}_{2}(100)$ surface with and without $\mathrm{H}_{2} \mathrm{O}$. For the reaction pathway without $\mathrm{H}_{2} \mathrm{O}$, IM1 was formed with $\mathrm{O}_{2}$ adsorbed on the surface. This shows that the process of $\mathrm{O}_{2}$ adsorption is exothermic with an energy of $107.86 \mathrm{~kJ} / \mathrm{mol}$. Subsequently, the $\mathrm{O}-\mathrm{O}$ bond of 
intermediate IM1 breaks into two active $\mathrm{O}$ atoms to form intermediate IM2 through the transition state TS1 by overcoming an energy barrier of $14.38 \mathrm{~kJ} / \mathrm{mol}$. This reaction step (IM1 $\rightarrow$ TS $1 \rightarrow \mathrm{IM} 2$ ) is an exothermic process with $110.00 \mathrm{~kJ} / \mathrm{mol}$. The length between two $\mathrm{O}$ atoms increases for this elementary reaction step: $1.446 \AA$ (IM1) $\rightarrow 1.731 \AA$ (TS1) $\rightarrow 3.403 \AA$ (IM2). The intermediate IM2 transforms into the intermediate IM3 via the transition state TS2. For structure IM3, two active O atoms are both attached to As atoms. This reaction process (IM2 $\rightarrow$ TS2 $\rightarrow$ IM3) is a mid-range exothermic $(72.72 \mathrm{~kJ} / \mathrm{mol})$ step with a low energy barrier of $7.18 \mathrm{~kJ} / \mathrm{mol}$. The intermediate IM3 transforms into the intermediate IM4 through the transition state TS3 after crossing an energy barrier of $47.12 \mathrm{~kJ} / \mathrm{mol}$. In addition, this reaction step (IM3 $\rightarrow \mathrm{TS} 3 \rightarrow \mathrm{IM} 4$ ) is an exothermic process with $52.73 \mathrm{~kJ} / \mathrm{mol}$. For the last step (IM4 $\rightarrow \mathrm{TS} 4 \rightarrow \mathrm{FS}$ ), the As atom has broken away from the surface and arsenic oxide is obtained. The process is endothermic $(32.33 \mathrm{~kJ} / \mathrm{mol})$ step with a high energy barrier of $116.05 \mathrm{~kJ} / \mathrm{mol}$.

For the pathway with $\mathrm{H}_{2} \mathrm{O}$, the reaction process of arsenic oxide formation on the $\mathrm{FeS}_{2}$ (100) surface is similar to that without $\mathrm{H}_{2} \mathrm{O}$, and the process of $\mathrm{O}_{2}$ adsorption is exothermic with an energy of $123.46 \mathrm{~kJ} / \mathrm{mol}$, which is larger than that $(107.86 \mathrm{~kJ} / \mathrm{mol})$ without $\mathrm{H}_{2} \mathrm{O}$. The result shows that the $\mathrm{O}_{2}$ molecule is more likely to adsorb on the $\mathrm{FeS}_{2}(100)$ surface with $\mathrm{H}_{2} \mathrm{O}$, promoting arsenic oxide formation. Subsequently, the two $\mathrm{O}$ atoms of the $\mathrm{O}_{2}$ molecule moved away from each other, and the length of the $\mathrm{O}-\mathrm{O}$ bond increases gradually. This reaction step (IM1' $\rightarrow \mathrm{TS} 1^{\prime} \rightarrow \mathrm{IM} 2$ ') is an exothermic process with $126.53 \mathrm{~kJ} / \mathrm{mol}$ and must overcome an energy barrier of $13.83 \mathrm{~kJ} / \mathrm{mol}$. The intermediate IM2' transforms into the intermediate IM3' through the transition state TS2' after crossing an energy barrier of $24.02 \mathrm{~kJ} / \mathrm{mol}$. This reaction step (IM2' $\rightarrow$ TS2' $\rightarrow$ IM3') is an exothermic process $(46.11 \mathrm{~kJ} / \mathrm{mol})$. This reaction process (IM3' $\rightarrow$ TS3 ${ }^{\prime} \rightarrow \mathrm{IM}^{\prime}$ ') is an exothermic $(33.26 \mathrm{~kJ} / \mathrm{mol})$ step with a medium energy barrier of $43.65 \mathrm{~kJ} / \mathrm{mol}$. According to the theory of reaction rate determination, the rate-determining step is from IM4 (IM4') to FS (FS'). The energy barrier of the last elementary reaction process (IM4 $\rightarrow \mathrm{TS}^{\prime} \rightarrow \mathrm{FS}^{\prime}$ ) is $98.49 \mathrm{~kJ} / \mathrm{mol}$, lower than that (116.05 kJ/mol) of the rate-determining step without $\mathrm{H}_{2} \mathrm{O}$. It is thus concluded that arsenic oxide formation on the $\mathrm{FeS}_{2}$ (100) surface with pre-adsorbed $\mathrm{H}_{2} \mathrm{O}$ is more likely to occur.

\subsection{Thermodynamic analysis}

From the above reaction process analysis, the reaction pathway and energy variation of arsenic oxide formation on the $\mathrm{FeS}_{2}$ (100) surface with and without $\mathrm{H}_{2} \mathrm{O}$ were well understood. The thermodynamic parameters Gibbs free energy, G, and equilibrium constant, $\mathrm{K}$, which are helpful for further understanding the reaction process, were calculated under different reaction temperatures. The thermodynamic parameters of arsenic oxide formation with and without $\mathrm{H}_{2} \mathrm{O}$ are calculated at $298.15 \mathrm{~K}$ to $1500 \mathrm{~K}$, and the Gibbs free energy difference $(\Delta \mathrm{G})$ and logarithm of equilibrium constants are listed in Table 4.

Table 4. Thermodynamic parameters at different temperatures.

\begin{tabular}{|c|c|c|c|c|}
\hline \multirow{2}{*}{$\begin{array}{c}\text { Temperature } \\
\text { (K) }\end{array}$} & \multicolumn{2}{|c|}{ Without $\mathrm{H}_{2} \mathrm{O}$} & \multicolumn{2}{|c|}{ With $\mathrm{H}_{2} \mathrm{O}$} \\
\hline & $\Delta \mathrm{G}(\mathrm{kJ} / \mathrm{mol})$ & $\operatorname{Ln}(\mathrm{K})$ & $\Delta \mathrm{G}(\mathrm{kJ} / \mathrm{mol})$ & $\operatorname{Ln}(K)$ \\
\hline 298.15 & -250.44 & 100.37 & -252.99 & 101.40 \\
\hline 500 & -203.37 & 48.90 & -205.92 & 49.52 \\
\hline 700 & -153.48 & 26.36 & -156.03 & 26.80 \\
\hline 900 & -101.38 & 13.54 & -103.94 & 13.89 \\
\hline 1100 & -47.55 & 5.20 & -50.10 & 5.48 \\
\hline
\end{tabular}




\begin{tabular}{lllll}
1300 & 7.71 & -0.71 & 5.16 & -0.48 \\
1500 & 64.17 & -5.14 & 61.62 & -4.94 \\
\hline
\end{tabular}

From Table 4, the Gibbs free energy difference $(\Delta \mathrm{G})$ gradually increases from -252.99 to 61.62 $\mathrm{kJ} / \mathrm{mol}$ with $\mathrm{H}_{2} \mathrm{O}$, and from -250.44 to $64.17 \mathrm{~kJ} / \mathrm{mol}$ without $\mathrm{H}_{2} \mathrm{O}$ when temperatures rise from $298.15 \mathrm{~K}$ to $1500 \mathrm{~K}$. According to the Gibbs free energy principle, $\Delta \mathrm{G}<0$ means that the reaction can occur spontaneously. Therefore, arsenic oxide formation on the $\mathrm{FeS}_{2}(100)$ surface with and without $\mathrm{H}_{2} \mathrm{O}$ is weakened with increasing temperature. The Gibbs free energy difference of arsenic oxide formation is less than zero when the reaction temperature is below $1100 \mathrm{~K}$, which indicates that the arsenic oxide formation reaction can take place spontaneously. In addition, the equilibrium constant is also an important thermodynamic parameter, which can clarify the degree of the reaction. As shown in Table 4, the equilibrium constant of reaction with $\mathrm{H}_{2} \mathrm{O}$ is slightly higher than that of reaction without $\mathrm{H}_{2} \mathrm{O}$, which suggests that the degree of the chemical reaction increases in the presence of $\mathrm{H}_{2} \mathrm{O}$. These results confirm that more arsenic oxide will be formed in the presence of $\mathrm{H}_{2} \mathrm{O}$, which can contribute to the release of arsenic during coal combustion.

\subsection{Kinetic analysis}

Kinetic parameters of chemical reaction can be calculated to provide a foundation for microkinetics investigation. Based on the above reaction pathway analysis, the rate-determining steps of the arsenic oxide formation reaction with and without $\mathrm{H}_{2} \mathrm{O}$ were chosen to conduct the kinetic analysis. According to the conventional transition state theory, kinetic parameters were calculated at 298.15-1500 K, and the calculation results are presented in Fig. 7.

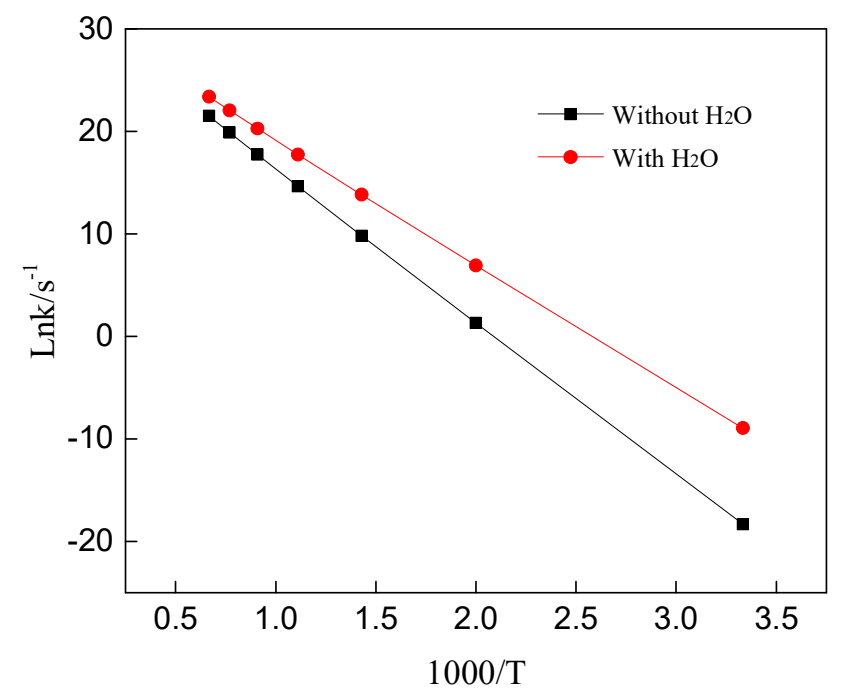

Fig. 7. The logarithm of reaction rate constants of rate-determining steps.

From Fig. 7, it can be seen that the reaction rate constants increase with temperature, suggesting that arsenic oxide formation is greatly influenced by the reaction temperature. From Fig. 7, the reaction rate of arsenic oxide formation with $\mathrm{H}_{2} \mathrm{O}$ is always greater than that without $\mathrm{H}_{2} \mathrm{O}$ in the studied temperature range. Additionally, pre-exponential factor (A) and activation energy (Ea) were calculated by the vertical intercept and slope of the line, as listed in Table 5 .

Table 5. Reaction kinetic parameters.

\begin{tabular}{ccc}
\hline Reaction & Pre-exponential factor $\mathrm{A}\left(\mathrm{s}^{-1}\right)$ & Activation energy Ea $(\mathrm{kJ} / \mathrm{mol})$ \\
\hline Without $\mathrm{H}_{2} \mathrm{O}$ & $3.92 \times 10^{13}$ & 124.08 \\
With $\mathrm{H}_{2} \mathrm{O}$ & $3.91 \times 10^{13}$ & 100.72 \\
\hline
\end{tabular}


From Table 5 it can be seen that the pre-exponential factors of the reaction with and without $\mathrm{H}_{2} \mathrm{O}$ are similar, and the activation energy $(100.72 \mathrm{~kJ} / \mathrm{mol})$ of the arsenic oxide formation reaction with $\mathrm{H}_{2} \mathrm{O}$ is lower than that $(124.08 \mathrm{~kJ} / \mathrm{mol})$ without $\mathrm{H}_{2} \mathrm{O}$. Therefore, these calculation results demonstrate that $\mathrm{H}_{2} \mathrm{O}$ has a positive effect on arsenic oxide formation on the $\mathrm{FeS}_{2}$ (100) surface.

\section{Conclusions}

An isothermal thermogravimetric reactor was employed to investigate the influence of $\mathrm{H}_{2} \mathrm{O}$ on the arsenic release behavior during combustion. To clarify the mechanism for the influence of $\mathrm{H}_{2} \mathrm{O}$, theoretical analyses were conducted to investigate the oxidation mechanism for arsenic via DFT, and thermodynamic and kinetic analyses were conducted to study the influence of temperature on the reaction. The following main conclusions can be drawn:

(1) The experimental results show that $\mathrm{H}_{2} \mathrm{O}$ has a positive influence on the release of arsenic during coal combustion.

(2) From the thermodynamic analysis, arsenic oxide formation on the $\mathrm{FeS}_{2}(100)$ surface with and without $\mathrm{H}_{2} \mathrm{O}$ weakens with increasing temperature, and that the chemical reaction can take place spontaneously below $1100 \mathrm{~K}$.

(3) The equilibrium constant of the reaction with $\mathrm{H}_{2} \mathrm{O}$ is slightly higher than that of the reaction without $\mathrm{H}_{2} \mathrm{O}$, which suggests that the degree of the chemical reaction with $\mathrm{H}_{2} \mathrm{O}$ is strengthened.

(4) From the kinetic analysis, the reaction rate constants increase with temperature, and the activation energy of the arsenic oxide formation reaction with and without $\mathrm{H}_{2} \mathrm{O}$ is $100.72 \mathrm{~kJ} / \mathrm{mol}$ and $124.08 \mathrm{~kJ} / \mathrm{mol}$, respectively. It is concluded that arsenic oxide formation on the $\mathrm{FeS}_{2}(100)$ surface with pre-adsorbed $\mathrm{H}_{2} \mathrm{O}$ is more likely to occur.

In this paper, arsenic release behavior was investigated via experiment and first-principles density functional theory. These elucidate the mechanism for $\mathrm{H}_{2} \mathrm{O}$ 's influence on arsenic oxidation, and lay a theoretical foundation for the emission and control of arsenic during coal combustion.

\section{Acknowledgements}

This work was supported by the National Natural Science Foundation of China (51976059) and the Fundamental Research Funds for the Central Universities (2018ZD03).

\section{References:}

[1] D. Chen, H. Hu, Z. Xu, H. Liu, J. Cao, J. Shen, H. Yao. Findings of proper temperatures for arsenic capture by $\mathrm{CaO}$ in the simulated flue gas with and without $\mathrm{SO}_{2}$. Chem. Eng. J. 267 (2015) 201-206.

[2] R. Huang, R. Cheng, M. Jing, L. Yang, Y. Li, Q. Chen, Y. Chen, J. Yan, C. Lin, Y. Wu, R. Zhang, I.E. Haddad, A.S.H. Prevot, C.D.O. Dowd, J. Cao. Source-specific health risk analysis on particulate trace elements: Coal combustion and traffic emission As major contributors in wintertime Beijing. Environ. Sci. Technol. 52 (2018) 10967-10974.

[3] S. Zhao, Y. Duan, C. Chen, H. Wu, D. Liu, M. Liu, J. Lu, X. Gu. Distribution and speciation transformation of hazardous trace element arsenic in particulate matter of a coal-fired power plant. Energ. Fuel. 32 (2018) 6049-6055.

[4] W. Yang, Z. Gao, X. Liu, X. Ding, W. Yan. The adsorption characteristics of $\mathrm{As}_{2} \mathrm{O}_{3}, \mathrm{~Pb}^{0}, \mathrm{PbO}$ and $\mathrm{PbCl}_{2}$ on single atom iron adsorbent with graphene-based substrates. Chem. Eng. J. 361 (2019) 304- 
313.

[5] C. Wang, H. Liu, Y. Zhang, C. Zou, E.J. Anthony. Review of arsenic behavior during coal combustion: Volatilization, transformation, emission and removal technologies. Prog. Energ. Combust. 68 (2018) 1-28.

[6] G. Liu, L. Zheng, N.S. Duzgoren-Aydin, L. Gao, J. Liu, Z. Peng. Health effects of arsenic, fluorine, and selenium from indoor burning of Chinese coal. Rev. Environ. Contam. T. 189 (2007) 89-106.

[7] C. Zhao, K. Luo. Household consumption of coal and related sulfur, arsenic, fluorine and mercury emissions in China. Energ. Policy 112 (2018) 221-232.

[8] Y.E. Yudovich, M.P. Ketris. Arsenic in coal: a review. Int. J. Coal Geol. 61 (2005) 141-196.

[9] C. He, S. Ma, X. Su, Q. Mo. Microwave roasting pyrite for removal of the sulfur and arsenic. Advanced Materials Research 881-883 (2014) 1531-1535.

[10] W. Cheng, Q. Zhang, R. Yang, Y. Tian. Occurrence modes and cleaning potential of sulfur and some trace elements in a high-sulfur coal from Pu'an coalfield, SW Guizhou, China. Environ. Earth Sci. 72 (2014) 35-46.

[11] K. Savage, P. O'Day, G. Waychunas, D. Bird, T. Tingle. Arsenic speciation in pyrite and secondary weathering phases, Mother Lode Gold District, Tuolumne County, California. Appl. Geochem. 15 (2000) 1219-1244.

[12] L.F. Ruppert, J.C. Hower, C.F. Eble. Arsenic-bearing pyrite and marcasite in the Fire Clay coal bed, Middle Pennsylvanian Breathitt Formation, eastern Kentucky. Int. J. Coal Geol. 63 (2005) 27-35.

[13] P. Le Pape, M. Blanchard, J. Brest, J. Boulliard, M. Ikogou, L. Stetten, S. Wang, G. Landrot, G. Morin. Arsenic incorporation in pyrite at ambient temperature at both tetrahedral S-I and octahedral FeII sites: Evidence from EXAFS - DFT analysis. Environ. Sci. Technol. 51 (2017) 150-158.

[14] G. Chen, Y. Sun, B. Yan, R. Yang, B. Liu, Z. Cheng, W. Ma. Distribution of trace elements during coal gasification: The effect of upgrading method. J. Clean. Prod. 190 (2018) 193-199.

[15] A. Nzihou, B. Stanmore. The fate of heavy metals during combustion and gasification of contaminated biomass-A brief review. J. Hazard. Mater. 256-257 (2013) 56-66.

[16] H. Liu, W. Pan, C. Wang, Y. Zhang. Volatilization of arsenic during coal combustion based on isothermal thermogravimetric analysis at 600-1500 ${ }^{\circ} \mathrm{C}$. Energ. Fuel. 30 (2016) 6790-6798.

[17] C. Zou, C. Wang, H. Liu, L. Chen, E. Anthony. Effect of $\mathrm{H}_{2} \mathrm{O}$ on the volatilization characteristics of arsenic during isothermal $\mathrm{O}_{2} / \mathrm{CO}_{2}$ combustion. Int. J. Greenh. Gas Con. 83 (2019) 228-235.

[18] H. Liu, C. Wang, C. Zou, Y. Zhang, J. Wang. Simultaneous volatilization characteristics of arsenic and sulfur during isothermal coal combustion. Fuel 203 (2017) 152-161.

[19] M.L. Contreras, J.M. Arostegui, L. Armesto. Arsenic interactions during co-combustion processes based on thermodynamic equilibrium calculations. Fuel 88 (2009) 539-546.

[20] H. Liu, C. Wang, X. Sun, Y. Zhang, C. Zou. Volatilization of arsenic in coal during isothermal oxyfuel combustion. Energ. Fuel. 30 (2016) 3479-3487.

[21] C. Zou, C. Wang. Theoretical study of the reactions between arsenic and nitrogen oxides during coal combustion. J. Mol. Model. 25 (2019).

[22] M. Monahan-Pendergast, M. Przybylek, M. Lindblad, J. Wilcox. Theoretical predictions of arsenic and selenium species under atmospheric conditions. Atmos. Environ. 42 (2008) 2349-2357.

[23] J. Luo, X. Meng, J. Crittenden, J. Qu, C. Hu, H. Liu, P. Peng. Arsenic adsorption on $\alpha-\mathrm{MnO}_{2}$ nanofibers and the significance of ( $\left.\begin{array}{lll}1 & 0 & 0\end{array}\right)$ facet as compared with $\left(\begin{array}{lll}1 & 1 & 0\end{array}\right)$. Chem. Eng. J. 331 (2018) 492-500.

[24] X. Du, J. Tang, X. Gao, Y. Chen, J. Ran, L. Zhang. Molecular transformations of arsenic species in 
the flue gas of typical power plants: A density functional theory study. Energ. Fuel. 30 (2016) 42094214.

[25] W. Qu, J. Liu, F. Shen, P. Wei, Y. Lei. Mechanism of mercury-iodine species binding on carbonaceous surface: insight from density functional theory study. Chem. Eng. J. 306 (2016) 704708.

[26] C. Zou, C. Wang, H. Liu, H. Wang, Y. Zhang. Effect of volatile and ash contents in coal on the volatilization of arsenic during isothermal coal combustion. Energ. Fuel. 31 (2017) 12831-12838.

[27] J.P. Perdew, K. Burke, M. Ernzerhof. Generalized gradient approximation made simple. Phys. Rev. Lett. 77 (1996) 3865-3868.

[28] G. Kresse, D. Joubert. From ultrasoft pseudopotentials to the projector augmented-wave method. Physical Review B Condensed Matter 59 (1999) 1758-1775.

[29] G. Kresse, J. Furthmuller. Efficiency of ab-initio total energy calculations for metals and semiconductors using a plane-wave basis set. Comp. Mater. Sci. 6 (1996) 15-50.

[30] G. Henkelman, H. Jonsson. Improved tangent estimate in the nudged elastic band method minimum energy paths and saddle points. The Journal of Chemical Physics 113 (2000) 9978-9985.

[31] N. Hamdadou, A. Khelil, J.C. Bernède. Pyrite $\mathrm{FeS}_{2}$ films obtained by sulphuration of iron predeposited films. Mater. Chem. Phys. 78 (2003) 591.

[32] A.M. Karguppikar, A.G. Vedeshwar. Transport properties of thin iron pyrite films. Physica Status Solidi. C 95 (1986) 717-720.

[33] P.A. Korevaar, S.J. George, A.J. Markvoort, M.M.J. Smulders, P.A.J. Hilbers, A.P.H.J. Schenning, T.F.A. De Greef, E.W. Meijer. Pathway complexity in supramolecular polymerization. Nature 481 (2012) 492-496.

[34] K. Reuter, M. Scheffler. Composition, structure and stability of $\mathrm{RuO}_{2}(110)$ as a function of oxygen pressure. Physical Review B Condensed Matter 65 (2001) 321-325.

[35] C. Ling, L. Shi, Y. Ouyang, X. Zeng, J. Wang. Nanosheet supported single-metal atom bifunctional catalyst for overall water splitting. Nano Lett. 17 (2017) 5133-5139.

[36] W. Yang, Z. Gao, X. Ding. The adsorption characteristics of mercury species on single atom iron catalysts with different graphene-based substrates. Appl. Surf. Sci. 455 (2018) 940-951.

[37] G. Bravo-Perez, J.R. Alvarez-Idaboy, A. Cruz-Torres, M.E. Ruiz. Quantum chemical and conventional transition-state theory calculations of rate constants for the $\mathrm{NO}_{3}$ plus alkane reaction. J. Phys. Chem. A 106 (2002) 4645-4650.

[38] A. Jiao, H. Zhang, J. Liu, J. Shen, X. Jiang. The role of CO played in the nitric oxide heterogeneous reduction: A quantum chemistry study. Energy 141 (2017) 1538-1546.

[39] R.A. Zielinski, A.L. Foster, G.P. Meeker, I.K. Brownfield. Mode of occurrence of arsenic in feed coal and its derivative fly ash, Black Warrior Basin, Alabama. Fuel 86 (2007) 560-572.

[40] Y. Yang, J. Liu, F. Liu, Z. Wang, Z. Zhang. Comprehensive evolution mechanism of $\mathrm{SO}_{\mathrm{x}}$ formation during pyrite oxidation. P. Combust. Inst. (2018) 1-11.

[41] J.M. Guevremont, J. Bebie. Reactivity of the (100) plane of pyrite in oxidizing gaseous and aqueous environments: Effects of surface imperfections. Environ. Sci. Technol. 32 (1998) 3743.

[42] M. Sacchi, M.C.E. Galbraith, S.J. Jenkins. The interaction of iron pyrite with oxygen, nitrogen and nitrogen oxides: a first-principles study. Phys. Chem. Chem. Phys. 14 (2012) 3627-3633.

[43] Y. Yang, J. Liu, F. Liu, Z. Wang, S. Miao. Molecular-level insights into mercury removal mechanism by pyrite. J. Hazard. Mater. 344 (2018) 104-112.

[44] S. Seddighi, P.T. Clough, E.J. Anthony, R.W. Hughes, P. Lu. Scale-up challenges and opportunities 
for carbon capture by oxy-fuel circulating fluidized beds. Appl. Energ. 232 (2018) 527-542.

[45] M.E. Mostafa, L. He, J. Xu, S. Hu, Y. Wang, S. Su, X. Hu, S.A. Elsayed, J. Xiang. Investigating the effect of integrated $\mathrm{CO}_{2}$ and $\mathrm{H}_{2} \mathrm{O}$ on the reactivity and kinetics of biomass pellets oxy-steam combustion using new double parallel volumetric model (DVM). Energy (2019).

[46] E. Hecht, C.R. Shaddix, M. Geier, A. Molina, B.S. Haynes. Effect of $\mathrm{CO}_{2}$ and steam gasifcation reactions on the oxy-combustion of pulverized coal char. Combust. Flame 159 (2012).

[47] H. Hu, H. Liu, J. Chen, A. Li, H. Yao, F. Low, L. Zhang. Speciation transformation of arsenic during municipal solid waste incineration. P. Combust. Inst. 35 (2015) 2883-2890.

[48] J.M. Guevremont, D.R. Strongin, M.A.A. Schoonen. Effects of surface imperfections on the binding of $\mathrm{CH}_{3} \mathrm{OH}$ and $\mathrm{H}_{2} \mathrm{O}$ on $\mathrm{FeS}_{2}(100)$ : Using adsorbed Xe as a probe of mineral surface structure. Surf. Sci. 391 (1997) 109-124.

[49] J.M. Guevremont, D.R. Strongin, M.A.A. Schoonen. Photoemission of adsorbed xenon, X-ray photoelectron spectroscopy, and temperature-programmed desorption studies of $\mathrm{H}_{2} \mathrm{O}$ on $\mathrm{FeS}_{2}(100)$. Langmuir 14 (1998) 1361-1366.

[50] R. Murphy, D.R. Strongin. Surface reactivity of pyrite and related sulfides. Surf. Sci. Rep. 64 (2009) $1-45$. 